\title{
Hubungan Stunting dengan Tingkat Keparahan Karies Gigi pada Anak Usia 10-12 Tahun di Kecamatan Tuah Negeri Kabupaten Musi Rawas
}

\author{
Abubakar Lutfi ${ }^{1}$, Rostika Flora ${ }^{2}$, Haerawati Idris ${ }^{3}$. Mohammad Zulkarnain ${ }^{4}$ \\ 1,2,3Program Studi Magister Ilmu Kesehatan Masyarakat, Fakultas Kesehatan Masyarakat, Universitas \\ Sriwijaya \\ ${ }^{4}$ Ilmu Kesehatan Masyarakat, Fakultas Kedokteran, Universitas Sriwijaya \\ Email: rostikaflora@gmail.com
}

Submitted : 09/06/2021

Accepted: 10/09/2021

Published: 15/09/2021

\begin{abstract}
Stunting is one of the most common malnutrition conditions. Stunting conditions can cause impaired child development including developmental disorders in the oral cavity. Stunting children are more susceptible to dental caries due to changes in saliva characteristics. This study aims to analyze the relationship between stunting and the severity of dental caries in elementary schoolaged children in Tuah Negeri District, Musi Rawas Regency. Methods: This study is an analytic observational study with a cross-sectional design. A sample of 70 people was taken randomly from elementary school students in Tuah Negeri District, Musi Rawas Regency. Determination of nutritional status based on anthropometric measurements $(T B / U)$. DMFT examination was carried out by looking at decaying, filling, and missing teeth, then the severity of dental caries was categorized into low (DMFT 0 - 2.6), moderate (DMFT 2.7 - 4.4), high (DMFT > 4.5). Data were analyzed using SPSS version 20 with Chi-Square Test analysis. Result: The results of the measurement of nutritional status showed that 34 children (48.6\%) were stunted. In stunting children, there are 15 children (44.12\%) in the low category, 16 children (47.06\%) in the medium category, 3 children (8.82\%) in the high category. The results of the bivariate analysis obtained $p$ $=0.000$. Conclussion: There is a significant relationship between stunting and the severity of dental caries in children aged 10-12 years in Tuah Negeri District, Musi Rawas Regency. It is necessary to increase efforts to promote health related to stunting and dental health through health education activities by involving the role of parents in choosing food intake and in maintaining children's dental and oral hygiene.
\end{abstract}

Keywords: dental caries, dmft, nutritional status, stunting

\begin{abstract}
Abstrak
Stunting merupakan salah satu kondisi malnutrisi yang paling umum terjadi. Kondisi stunting dapat menyebabkan perkembangan anak terganggu, termasuk gangguan perkembangan pada rongga mulut. Anak stunting lebih rentan untuk terkena karies gigi karena terjadi perubahan karakteristik saliva. Penelitian ini bertujuan untuk menganalisis hubungan stunting terhadap tingkat keparahan karies gigi pada anak usia sekolah dasar di Kecamatan Tuah Negeri Kabupaten Musi Rawas. Metode Penelitian: Penelitian ini merupakan penelitian observasional analitik dengan desain cross-sectional. Sampel berjumlah 70 orang yang diambil secara random dari siswa SD di Kecamatan Tuah Negeri Kabupaten Musi Rawas. Penentuan status gizi berdasarkan pengukuran antropometri (TB/U). Pemeriksaan DMFT dilakukan dengan melihat gigi yang mengalami decay, filling, dan missing, selanjutnya tingkat keparahan karies gigi dikategorikan menjadi rendah (DMFT 0 - 2.6), sedang (DMFT 2.7 - 4.4), tinggi (DMFT > 4.5). Data dianalisis menggunakan SPSS versi 20 dengan analisis Uji Chi-Square. Hasil: Hasil pengukuran status gizi didapatkan bahwa 34 anak (48.6\%) mengalami stunting. Pada anak stunting, terdapat 15 anak (44.12\%) yang memiliki nilai DMFT dengan kategori rendah, 16 anak (47.06\%) yang memiliki nilai DMFT dengan kategori sedang, 3 anak (8.82\%) yang memiliki nilai DMFT dengan kategori tinggi. Hasil analisis bivariat didapatkan $\mathrm{p}=0.000$. Kesimpulan: Terdapat hubungan yang signifikan antara stunting dan tingkat keparahan karies gigi pada anak usia 10-12 tahun di Kecamatan Tuah Negeri Kabupaten Musi Rawas. Perlu ditingkatkannya upaya promosi kesehatan terkait stunting dan
\end{abstract}


kesehatan gigi melalui kegiatan edukasi kesehatan dengan melibatkan peran orang tua dalam pemilihan asupan makanan dan dalam menjaga kebersihan gigi dan mulut anak.

Kata Kunci: dmft, karies gigi, status nutrisi, stunting

\section{PENDAHULUAN}

Stunting merupakan suatu kondisi dimana anak memiliki panjang atau tinggi badan yang kurang jika dibandingkan dengan umur. Kondisi tersebut merupakan suatu bentuk malnutrisi pada anak yang paling umum terjadi. (Sutarto, 2018).

Secara global, pada tahun 2013 diperkirakan terdapat 161 juta anak di bawah usia 5 tahun yang mengalami stunting. Data prevalensi balita stunting yang dikumpulkan World Health Organization (WHO), Indonesia termasuk ke dalam negara ketiga dengan prevalensi tertinggi di regional Asia Tenggara/SouthEast Asia Regional (SEAR) (Kemenkes RI, 2018). Prevalensi stunting pada anak usia sekolah (5-12 tahun) di Indonesia pada tahun pada tahun 2010 yaitu sebesar 28.3\%(Kemenkes RI, 2010). Pada tahun 2013 presentase stunting meningkat menjadi $31.7 \%$ (Kemenkes RI, 2013).

Sumatera Selatan menduduki peringkat ke 10 angka kejadian stunting di Indonesia (Kemenkes RI, 2018). Berdasarkan hasil Pemantauan Status Gizi (PSG) tahun 2018 di 17 kabupaten/kota seSumatera Selatan, Persentase Stunting pada Balita dalam lima tahun terakhir mengalami trend penurunan namun sedikit naik pada tahun 2017 dan 2018. Pada 2014 angka stunting sebesar $26.3 \%$, kemudian turun menjadi $24.5 \%$ pada tahun 2015 , turun lagi menjadi $19.30 \%$ pada tahun 2016 kemudian naik sedikit menjadi $22.8 \%$ pada tahun 2017 dan tetap sebesar $22.8 \%$ pada tahun 2018. Pada tahun 2018 persentase stunting pada Balita tertinggi pada kabupaten Banyuasin sebesar 32.8\%, sedangkan persentase Stunting pada Balita terendah pada kota Palembang sebesar 14.5\%. Sementara Kabupaten Musi Rawas masuk dalam 10 daerah tertinggi stunting dengan angka stunting sebesar 25.9\% (Dinkes prov. Sumsel., 2019).

Kondisi stunting dapat menyebabkan perkembangan anak terganggu diantaranya gangguan perkembangan pada rongga mulut. Anak stunting lebih rentan untuk terkena karies gigi karena terjadi perubahan karakteristik saliva seperti penurunan laju alir dan pH (Abdat et al., 2020). Karies gigi merupakan suatu penyakit yang disebabkan karena interaksi bakteri yang memproduksi asam dengan host (gigi), substrat (makanan), dan berkembang seiring berjalannya waktu. Asam yang dihasilkan bakteri akan menyebabkan menurunnya $\mathrm{pH}$, kemudian penurunan $\mathrm{pH}$ yang berulang-ulang dalam waktu tertentu akan mengakibatkan demineralisasi permukaan gigi dan proses karies akan terjadi (Fajerskov dan Kidd, 2008). Indeks yang digunakan untuk melihat keparahan karies gigi adalah indeks DMFT (decayed missing filling teeth) yang digunakan untuk gigi permanen dan deft (decayed extracted filling teeth) untuk gigi sulung. Indeks DMF-T yang dikeluarkan oleh WHO bertujuan untuk menggambarkan pengalaman karies seseorang atau dalam suatu populasi. Berdasarkan hasil Riskesdas (Riset Kesehatan Dasar) tahun 2013 didapatkan bahwa prevalensi nasional karies aktif di Indonesia adalah $53.2 \%$ dan prevalensi nasional indeks DMFT adalah 4.6. Indeks DMFT di provinsi Sumatra Selatan adalah 5.3 (Dinkes prov. Sumsel., 2019).

Status gizi anak usia sekolah merupakan lanjutan dari perkembangan status gizi usia balita. Berbagai penelitian pada balita menyebutkan stunting erat kaitannya dengan gangguan kognitif dan motorik, serta gangguan perkembangan pada rongga mulut. Penelitian ini bertujuan untuk menganalisis hubungan stunting terhadap tingkat keparahan karies gigi pada 
anak usia sekolah dasar di Kecamatan Tuah Negeri Kabupaten Musi Rawas.

\section{METODE PENELITIAN}

Penelitian ini merupakan jenis penelitian observasional analitik dengan desain cross-sectional. Penelitian ini dilakukan di Sekolah Dasar (SD) Kecamatan Tuah Negeri Kabupaten Musi Rawas. Penelitian dilakukan pada bulan Maret Tahun 2021. Sampel penelitian ini adalah siswa SD di Kecamatan Tuah Negeri Kabupaten Musi Rawas yang berjumlah 70 orang. Siswa SD dipilih secara acak menggunakan metode simple random sampling. Respoden yang memakai alat ortodonti, responden yang menderita penyakit kronis, dan responden yang sedang dalam pengobatan atau mengkonsumsi obat dalam kurun waktu 30 hari terakhir tidak diikutkan dalam penelitian. Penentuan status gizi berdasarkan antropometri menggunakan software Anthro 1.02. Tinggi badan diukur dan dikelompokkan sesuai Zscore menjadi stunting $(\leq 2 \mathrm{SD})$ dan tidak stunting ( $\geq 2 \mathrm{SD})$.

Dilakukan pemeriksaan indeks DMFT berdasarkan WHO melalui pemeriksaan klinis pada rongga mulut menggunakan diagnostic set disposable dan pencahayaan dari headlamp. Pemeriksaan dilakukan untuk melihat gigi yang mengalami decay (karies gigi), filling (gigi yang ditambal karena karies), missing (gigi yang hilang karena karies). Peneliti menulis hasil pemeriksaan dilembar pemeriksaan anak, dan menghitung indeks DMF-T. Tingkat keparahan karies gigi dikategorikan menjadi rendah (DMFT 0 - 2.6), sedang (DMFT 2.7 - 4.4), dan tinggi (DMFT > 4.5).

Data selanjutnya dianalisis menggunakan SPSS versi 20. Data dianalisis menggunakan Uji Chi-Square untuk mengetahui hubungan antara status gizi dengan tingkat keparahan karies gigi. Penelitian ini telah mendapatkan persetujuan dari komisi etik penelitian kesehatan Fakultas Kesehatan Masyarakat Universitas Sriwijaya No: 089/UN9.FKM/TU.KKE/2021.

\section{HASIL DAN PEMBAHASAN}

Data distribusi frekuensi karakteristik anak (Tabel 1) menunjukkan bahwa 54.3\% anak berjenis kelamin perempuan dengan usia 10-12 tahun dan 48.6\% anak mengalami stunting. Sebanyak $70 \%$ anak memiliki nilai DMFT (tingkat keparahan karies) yang tergolong rendah, 25.7\% anak memiliki nilai DMFT (tingkat keparahan karies) yang tergolong sedang, dan $4.3 \%$ anak memiliki nilai DMFT (tingkat keparahan karies) yang tergolong tinggi.

\section{Tabel 1. Distribusi Frekuensi Data karakteristik Anak dan Orangtua}

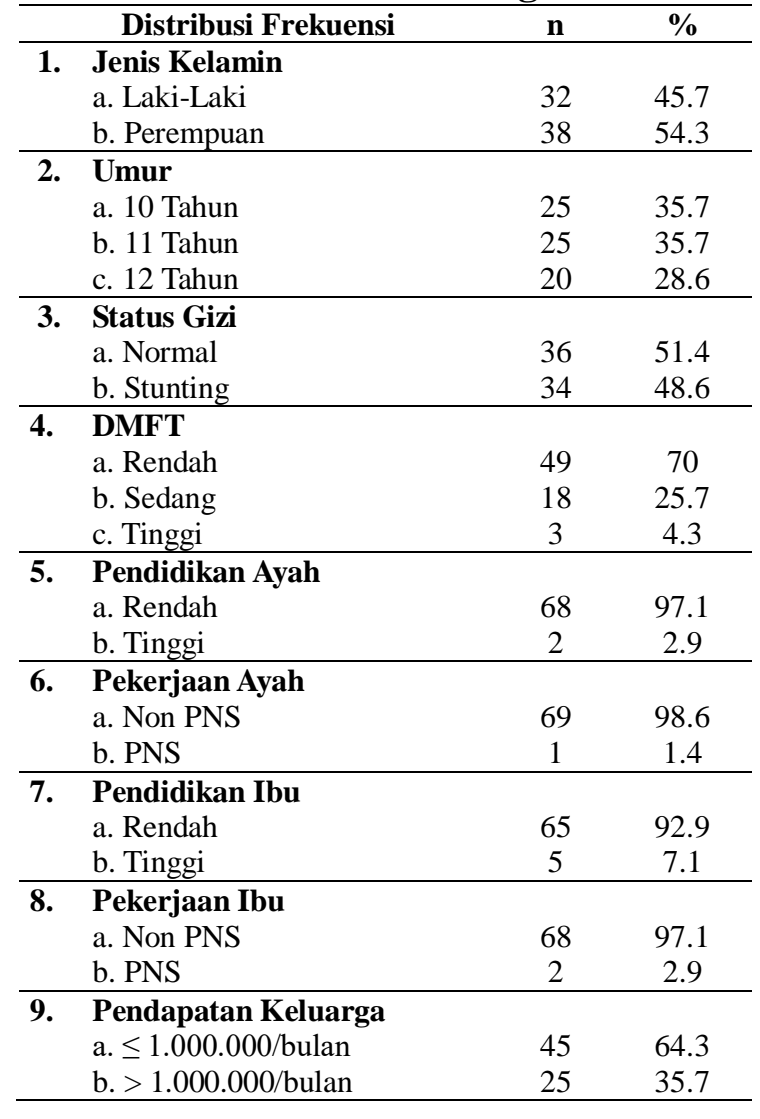

Pada penelitian ini, masalah nutrisi kemungkinan disebabkan oleh tingkat pendidikan dan status ekonomi orang tua. Data distribusi frekuensi karakteristik orang tua menunjukkan bahwa hampir 
keseluruhan orang tua berpendidikan rendah $(97.1 \%$ ayah dan $92.9 \%$ ibu), hampir keseluruhan orang tua bekerja sebagai non PNS (98.6\% ayah dan $97.1 \%$ ibu), mayoritas perkerjaan orang tua adalah sebagai petani. Total pendapatan keluarga mayoritas $\leq 1.000 .000 /$ bulan yakni sebanyak 64.3\% (Tabel 1).

Konsep WHO menyebutkan bahwa faktor resiko stunting di indonesia berupa variabel tinggi badan ibu, persalinan prematur, BBLR, lama melahirkan, pendidikan ibu rendah, penyakit menular, dan sosial ekonomi keluarga merupakan faktor risiko stunting di Indonesia (Beal, 2018).

Pendapatan keluarga merupakan salah satu indikator sosial ekonomi untuk memenuhi dan mencukupi kebutuhan dalam keluarga, hal ini didukung oleh temuan penelitian yang menyebutkan bahwa keluarga berpenghasilan rendah Stunting beresiko terhadap stunting (Illahi, 2017)rotal

Hasil penelitian yang dilakukan Nadiyah (2014) yang dilakukan di 3 provinsi di Indonesia Bali, Jawa Barat, dan NTT menunjukkan bahwa faktor risiko stunting adalah pendapatan ayah yang rendah. Sedangkan penelitian yang dilakukan di Semarang menunjukkan bahwa status sosial ekonomi keluarga yang rendah berisiko 11 kali lipat mempunyai anak stunting (Al-Anshori dan Nuryanto, 2013).

Mayoritas orang tua pada penelitian ini memiliki tingkat pendidikan yang tergolong rendah. Pendidikan merupakan faktor terbesar dari yang mempengaruhi status kesehatan. Pendidikan orang tua sangat penting dalam tumbuh kembang anak, terutama pendidikan ibu. Ibu yang berpendidikan tinggi lebih selektif dan kreatif dalam memberikan makanan bergizi untuk anak. Hasil penelitian Nkurunziza et al., (2017) menunjukkan bahwa rendahnya pendidikan ibu berisiko 1,6 kali lipat mengalami stunting. Penelitian lain yang dilakukan di Banjar Baru menunjukkan rendahnya pendidikan ibu menyebabkan anak mengalami stunting 5,1 kali (Rahayu et al., 2015).

Hasil uji statistik tentang hubungan antara stunting dan tingkat keparahan karies gigi (Tabel 2) didapatkan bahwa $44.12 \%$ anak stunting memiliki nilai DMFT dengan kategori rendah, $47.06 \%$ anak stunting memiliki nilai DMFT dengan kategori sedang, $8.82 \%$ anak stunting memiliki nilai DMFT dengan kategori tinggi. Terdapat hubungan yang bermakna antara stunting dan tingkat keparahan karies gigi $(\mathrm{p}=0.000)$.

Tabel 2. Hubungan Antara Stunting dan Tingkat Keparahan Karies (DMFT)

\begin{tabular}{|c|c|c|c|c|c|c|c|c|}
\hline \multicolumn{6}{|c|}{ Tingkat Keparahan Karies (DMFT) } & \multirow{2}{*}{\multicolumn{2}{|c|}{ Total }} & \multirow{3}{*}{$\mathrm{p}$} \\
\hline \multicolumn{2}{|c|}{ Rendah } & \multicolumn{2}{|c|}{ Sedang } & \multicolumn{2}{|c|}{ Tinggi } & & & \\
\hline $\mathrm{n}$ & $\%$ & $\mathrm{n}$ & $\%$ & $\mathrm{n}$ & $\%$ & $\mathrm{n}$ & $\%$ & \\
\hline 34 & 94.45 & 2 & 5.55 & 0 & 0 & 36 & 100 & \\
\hline 15 & 44.12 & 16 & 47.06 & 3 & 8.82 & 34 & 100 & 0.000 \\
\hline 49 & 70 & 18 & 25.71 & 3 & 4.29 & 70 & 100 & \\
\hline
\end{tabular}

Hasil penelitian ini sejalan dengan Abdat et al. (2020), yang menyebutkan terdapat korelasi yang kuat antara stunting dan kesehatan gigi dan mulut. Penelitian Abadi dan Abral (2020) juga menyatakan bahwa terdapat pola tertentu karies gigi pada penderita stunting dan ada hubungan yang signifikan antara faktor risiko dengan indeks karies pada penderita stunting. Hasil penelitian Folayan et al. (2019) tentang asosiasi antara ECC (Early Childhood Caries) dan malnutrisi pada populasi suburban di Nigeria juga menyebutkan bahwa malnutrisi seperti stunting, underweight, overweight merupakan indikator resiko terhadap ECC.

Anak stunting lebih rentan terhadap kejadian karies gigi karena terjadi perubahan karakteristik saliva seperti penurunan laju alir dan $\mathrm{pH}$ saliva (Abdat $e t$ al., 2020). Penelitian Vieira et al (2020) tentang malnutrisi kronis dan status kesehatan mulut pada anak-anak usia 1-5 tahun, didapatkan hasil bahwa malnutrisi 
menyebabkan dampak negatif terhadap kavitas rongga mulut anak-anak dan menyebabkan penurunan laju alir saliva. Stunting atau malnutrisi pada anak dapat menyebabkan laju alir (sekresi) saliva menurun (Doaa et al., 2016).

Saliva sangat penting dalam menjaga kesehatan rongga mulut. Laju aliran saliva yang baik memungkinkan untuk terjadinya pembersihan rongga mulut yang optimal. Saliva juga memiliki komponen antimikroba dan kemampuan menjaga keseimbangan $\mathrm{pH}$ rongga mulut (buffer) saat $\mathrm{pH}$ turun menjadi asam dan saat $\mathrm{pH}$ naik menjadi sangat basa, sehingga proses pembentukan karies dapat dicegah (Fatima et al., 2020). Berkurangnya sekresi saliva dapat disebabkan oleh kurangnya aktivitas pengunyahan yang dapat terjadi pada anak yang kurang asupan makanan (Abdat et al., 2020). Penurunan sekresi saliva dapat menyebabkan menurunnya kemampuan buffer dari saliva sehingga $\mathrm{pH}$ rongga mulut terganggu sehingga gigi lebih rentan untuk mengalami karies.

Karies gigi dapat menyebabkan dampak buruk dan dapat mempengaruhi kualitas hidup bagi anak. Karies akan menimbulkan rasa nyeri dan ketidaknyamanan. Hal ini akan mengganggu aktivitas anak di sekolah. Anak mengalami penurunan kemampuan dalam belajar (Zetu, 2014). Dampak lain yang muncul karena karies adalah anak dapat mengalami infeksi akut ataupun kronis, bahkan dapat menimbulkan kecacatan. Karies juga akan berpengaruh terhadap kualitas tidur anak dan pola makan anak karena rasa nyeri yang dirasakan. Kondisi ini akan mempengaruhi nutrisi, pertumbuhan dan pertambahan berat badan anak (Zetu, 2014).

\section{SIMPULAN}

Terdapat hubungan yang signifikan antara stunting dan tingkat keparahan karies gigi pada anak usia 10-12 tahun di
Kecamatan Tuah Negeri Kabupaten Musi Rawas.

\section{SARAN}

Perlu ditingkatkannya upaya promosi kesehatan terkait stunting dan kesehatan gigi melalui kegiatan edukasi kesehatan dengan melibatkan peran orang tua dalam pemilihan asupan makanan dan dalam menjaga kebersihan gigi dan mulut anak.

\section{UCAPAN TERIMAKASIH}

Terimakasih kepada Dinas Kesehatan Kabupaten Musirawas dan Puskesmas Air Beliti Kecamatan Tuah Negeri yang telah memfasilitasi pelaksanaan kegiatan penelitian ini.

\section{DAFTAR PUSTAKA}

Abdat M, Usman S, Chairunas, Suhaila H. Relationship Between Stunting With Dental And Oral Status In Toddlers. Journal of Dentomaxillofacial Science (J Dentomaxillofac Sci). 2020;5(2):114-119.

Al-Anshori H, Nuryanto N. Faktor Risiko Kejadian Stunting Pada Anak Usia 1224 Bulan (Studi di Kecamatan Semarang Timur). J Nutr Coll [Internet]. 2013;2(4):675-81.

Beal T, Tumilowicz A, Sutrisna A, Izwardy D, Neufeld L. A review of child stunting determinants in Indonesia. Matern Child Nutr. 2018;14:1-10.

Budiastutik I, Nugraheni SA. Determinants of Stunting in Indonesia: A Review Article. International Journal Of Healtcare Research. 2018:1(2);43-49.

Dinas Kesehatan Provinsi Sumatera Selatan. 2019. Rencana Kinerja Tahunan Dekonsentralisasi Dinas Kesehatan. 2019. (Diakses pada 7 Juni 2021). $\quad$ https://erenggar.kemkes.go.id/file2018/eperformance/2-119014-2tahunan581.pdf 
Doaa S.H et al. Effect of Childhood Malnutrition on Salivary Flow and $\mathrm{pH}$. ADJ-for Grils. 2016:3(2);141-145.

Fajerskov O, Kidd E. Dental Caries The Disease and its Clinical Management 3nd ed.. Australia: Blackwell Munksgard. 2015.

Fatima et al. Composition and Function of Saliva: A Review. The Journal of Pharmacy and Pharmaceutical Sciences. 2020:9(6);1552-1567.

Folayan MO et al. Association Between Early Childhood Caries And Malnutrition In a Sub-Urban Population In Nigeria. BMC Pediatrics. 2019:19(433);1-8.

Illahi RK. Hubungan Pendapatan Keluarga, Berat Lahir, Dan Panjang Lahir Dengan Kejadian Stunting Balita 24-59 Bulan Di Bangkalan. J Manaj Kesehat Yayasan RSDr Soetomo [Internet]. 2017;3(1):1-7.

Kemenkes RI. Laporan Hasil Riset Kesehatan Dasar Tahun 2010. Jakarta: Kementrian Kesehatan RI. 2010.

Kemenkes RI. Laporan Hasil Riset Kesehatan Dasar Tahun 2013. Jakarta: Kementrian Kesehatan RI. 2013.

Kemenkes RI. Laporan Hasil Riset Kesehatan Dasar Tahun 2018. Jakarta:Kementrian Kesehatan RI. 2018.

Nadiyah. Faktor Risiko Stunting Pada Anak Usia 0-23 Bulan Di Provinsi Bali, Jawa Barat, Dan Nusa Tenggara Timur. J Gizi dan Pangan. 2014;9(2):125-32.

Nkurunziza S, Meessen B, Van geertruyden JP, Korachais C. Determinants of stunting and severe stunting among Burundian children aged 6-23 months: Evidence from a national crosssectional household survey, 2014. BMC Pediatr. 2017;17(1):1-15.

Rahayu A, Yulidasari F, Putri AO, Rahman F. Riwayat Berat Badan Lahir dengan Kejadian Stunting pada Anak Usia Bawah Dua Tahun. Kesmas Natl Public Heal J [Internet]. 2015;10(2):67.
Sutarto, Mayasari D, Indriyani R. Stunting, Faktor Resiko dan Pencegahannya. J Agromedicine. 2018:5(1);540-545.

Vieira KA, et al. 2020. Chronic Malnutrition And Oral Health Status In Children Aged 1 To 5 Years. Medicine Journal. 2020:99(18);1-7.

Zetu, I., Zetu, L., Dogaru, C. B., Duta, C., Dumitrescu, A.L., 2014.Gender Varietion In Psychological Factor As Defined By The Theory Of Planned Of Oral Hygiene Behavior. ProcediaSocial And Behavioral. 2014:124(22);353- 357. 